\title{
THE COMPARATIVE CHEMICAL STUDY OF THE FATTY ACID COMPOSITION OF HAWTHORN FLOWERS OF SANGUINEAE SARG. SECTION
}

\author{
N.V.Sydora, A.M.Kovalyova, Yu.N.Avidzba, A.M.Komissarenko \\ National University of Pharmacy
}

Key words: hawthorn; flowers; fatty acids

\begin{abstract}
For the first time the comparative study of the fatty acid composition of flowers of C. almaatensis Pojark., C. kansuensis Wils., C. Schneideri C.K.Schneid and C. Maximowizchii C.K.Schneid of Sanguineae Sarg. section has been carried out by the chromato-mass-spectrometry method. For research the samples of the dried raw material, collected at the flower bud stage in the Botanical garden of the V.N.Karazin Kharkiv National University were used. The studies were carried out on an Agilent Technologies 6890 chromatograph with the mass-spectrometry detector 5973. As a result, 17 fatty acids have been identified. By the quantitative content such saturated fatty acids as laurinic, myristic, pentadecanic, palmitic, palmitoleic, heptadecanoic, stearic, oleic, linoleic, linolenic, arachinic, 2-oxypalmitic, cheneicosanic, behenic, hexadecanedicarbonic, tetracosanic and hexacosanoic dominate in all species studied. The unsaturated acids are presented by oleic, linoleic and linolenic acids. In flowers of C. almaatensis Pojark. 14 fatty acids, in C. kansuensis Wils. and C. Schneideri C.K.Schneid. 15 acids, in C. Maximowizchii C.K.Schneid. 17 acids have been identified. The content of fatty acids (calculated from the total amount) for C. almaatensis Pojark. flowers was as follows: saturated $-64.73 \%$, unsaturated $35.27 \%$; for C. kansuensis Wils. flowers: saturated - 65.59\%, unsaturated - 34.41\%; for C. Maximowizchii C.K.Schneid. flowers: saturated-57.71\%, unsaturated - 42.29\%; for C. Schneideri C.K. Schneid. flowers: saturated $-54.22 \%$, unsaturated $-45.78 \%$. The highest content (calculated with reference to the total amount of fatty acids) of oleic acid has been determined in C. almaatensis Pojark. flowers (4.5\%), linoleic acid - in C. kansuensis Wils. flowers (20.37\%), linolenic acid - in C. Maximowizchii C.K.Schneid. flowers (18.01\%).
\end{abstract}

Fatty acids are part of lipids and actively involved in metabolism, they are components of cell membranes, perform the function of storing and transport of energy and mechanical protection, reduce the blood cholesterol, have anti-inflammatory properties. The main sources of fatty acids are vegetable oils, milk and meat products, cereals, fish [7].

Crataegus L. (Hawthorn) genus includes more than 1500 species and is divided into 25 botanical sections $[2,5,8,9]$. Hawthorn flowers are used in medical practice as the raw material for obtaining of antihypertensive and sedative drugs [10]. This is due to their chemical composition presented by phenolic compounds (hydroxycinnamic acids, flavonoids, coumarins) and aminoacids $[1,3]$. As we reported earlier, a significant content of lipophilic compounds was identified in flowers of some unofficial species of hawthorn [4].

The aim of the work is to conduct the comparative chemical study of the fatty acid composition in flowers of C. almaatensis Pojark., C. kansuensis Wils., C. Schneideri C.K.Schneid. and C. Maximowizchii C.K.Schneid. in order to continue the phytochemical research of the representatives of Crataegus L. (Hawthorn) genus and expand the information about the chemical composition of the species from Sanguineae Sarg. section.

\section{Materials and Methods}

The study objects were flowers of C. Maximowizchii C.K.Schneid., C. kansuensis Wils., C. almaatensis Po- jark. and C. Scneideri C.K.Schneid. collected in May, 2014. The dried raw material was used. The raw material was collected at the flower bud stage.

Extract obtaining. Place $50 \mathrm{mg}$ of the raw material in a vial and add the internal standard $(50 \mathrm{mcg}$ of tridecane in hexane) and $1.0 \mathrm{ml}$ of a methylated agent (14\% $\mathrm{BCl}_{3}$ in methanol, Supelco 3-3033). Keep the mixture in a hermetically sealed vial for 8 hours at $65^{\circ} \mathrm{C}$. Pour the reaction mixture from the sediment of the plant material and dilute with $1 \mathrm{ml}$ of distilled water. To remove the methyl esters of fatty acids add $0.2 \mathrm{ml}$ of dichlormethane, stir for an hour from time to time. Chromatograph the extract of methyl esters obtained.

The study was carried out by the chromato-massspectrometry method on an Agilent Technologies 6890 chromatograph with the mass-spectrometry detector 5973 $[6,7]$. The chromatography parameters: introduction of the sample $(2 \mu 1)$ in the chromatographic column was performed in the splitless mode. The sample injection rate was $1.2 \mathrm{ml} / \mathrm{min}$ for $0.2 \mathrm{~min}$; the chromatographic column was capillary INNOWAX with the external diameter of $0.25 \mathrm{~mm}$ and the length of $30 \mathrm{~m}$; carrier gas (helium) was $1.2 \mathrm{ml} / \mathrm{min}$; the heater temperature was $250^{\circ} \mathrm{C}$.

To identify the components the library of mass-spectra NIST05 and WILEY 2007 with the total number of spectra more than 470000 in combination with AMDIS and NIST programmes for identification was used. For 
Fatty acids of hawthorn flowers

\begin{tabular}{|c|l|c|c|c|c|c|}
\hline \multirow{2}{*}{ No. } & \multirow{2}{*}{ The acid name } & Retention & \multicolumn{4}{|c|}{ Content $(\mathrm{mg} / \mathrm{kg})$} \\
\cline { 5 - 7 } & & index & C. almaatensis & C. kansuensis & C. Maximowizchii & C. Schneideri \\
\hline 1 & Laurinic & $19.76-19.85$ & 846.82 & 1810.65 & 312.33 & 66.57 \\
\hline 2 & Myristic & $24.14-24.26$ & 674.61 & 724.60 & 725.34 & 203.88 \\
\hline 3 & Pentadecanic & 26.04 & & & 76.24 & \\
\hline 4 & Palmitic & $28.08-28.24$ & 3813.34 & 4890.61 & 3170.74 & 3117.82 \\
\hline 5 & Palmitoleic & $28.32-28.66$ & 124.58 & 68.82 & 41.11 & 37.59 \\
\hline 6 & Heptadecanoic & $29.79-29.82$ & 90.88 & 71.13 & 59.59 & 57.29 \\
\hline 7 & Stearic & $31.56-31.75$ & 622.89 & 604.15 & 733.07 & 402.61 \\
\hline 8 & Oleic & $31.83-31.97$ & 544.30 & 214.64 & 389.68 & 235.26 \\
\hline 9 & Linoleic & $32.75-32.90$ & 2416.17 & 3285.62 & 2600.92 & 2159.97 \\
\hline 10 & Linolenic & $33.76-33.95$ & 1258.31 & 2047.70 & 2219.91 & 1618.42 \\
\hline 11 & Arachinic & $34.85-34.94$ & 321.64 & 408.62 & 660.90 & 369.85 \\
\hline 12 & $2-$-oxypalmitic & $35.48-35.93$ & & 243.89 & 81.13 & 114.01 \\
\hline 13 & Heneicosanic & $36.42-36.43$ & & & 69.61 & 41.42 \\
\hline 14 & Behenic & $37.91-38.01$ & 491.81 & 645.09 & 319.14 & 232.81 \\
\hline 15 & Hexadecanedicar-bonic & $38.50-38.57$ & 458.07 & 724.29 & 524.36 & \\
\hline 16 & Tetracosanic & $40.83-40.94$ & 140.92 & 291.7 & 274.21 & 164.01 \\
\hline 17 & Hexacosanoic & $44.37-44.68$ & 158.36 & 90.33 & 61.42 & 64.25 \\
\hline $\begin{array}{l}\text { Then } \\
\text { Tatty }\end{array}$ & & 7743.92 & 10573.88 & 7109.19 & 4872.11 \\
\hline $\begin{array}{l}\text { The amount of saturated } \\
\text { The total amount of }\end{array}$ & & 4218.78 & 5547.96 & 5210.51 & 4113.65 \\
\hline
\end{tabular}

quantitative calculation of the content of fatty acids the method of the internal standard was used.

\section{Results and Discussion}

In the raw material 17 fatty acids were identified. In flowers of $C$. almaatensis Pojark. - 14 fatty acids, in C. kansuensis Wils. and C. Schneideri C.K.Schneid. 15 acids, in C. Maximowizchii C.K.Schneid. -17 acids were identified. By the quantitative content such saturated fatty acids as palmitic and stearic dominate in all species studied. The unsaturated acids are presented by oleic, linoleic and linolenic acids.

For C. Maximowizchii C.K.Schneid. flowers pentadecanic acid $(76.24 \mathrm{mg} / \mathrm{kg})$ is individual, and heneicosanic acid $(69.61 \mathrm{mg} / \mathrm{kg})$ with the content of $41.42 \mathrm{mg} / \mathrm{kg}$ is individual for C. Schneideri C.K.Schneid. flowers.

The results of the study are shown in Table and Fig. 1-4.

The content of fatty acids (calculated to the total amount) for flowers of $C$. almaatensis Pojark. was:

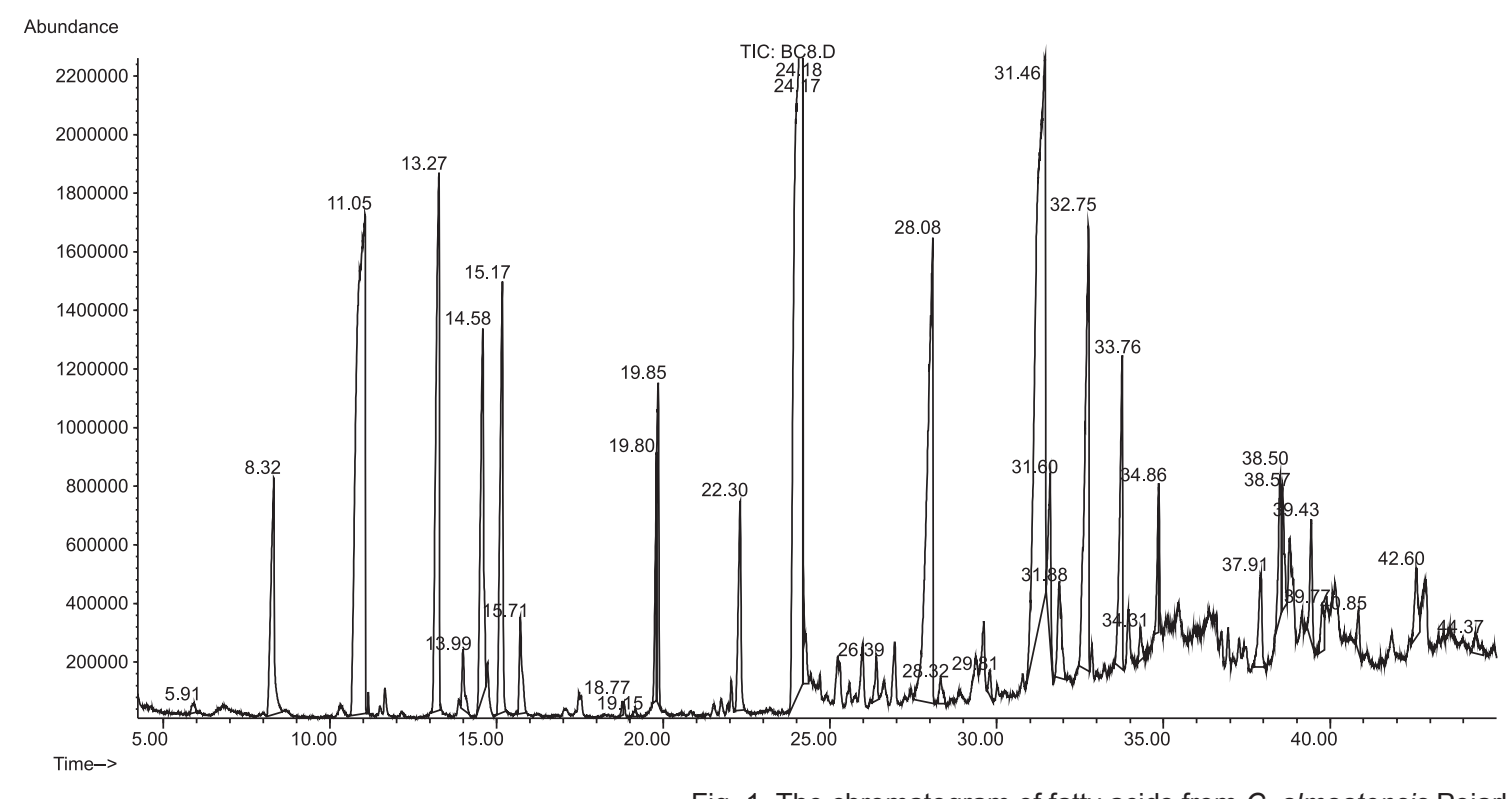

Fig. 1. The chromatogram of fatty acids from C. almaatensis Pojark. flowers. 


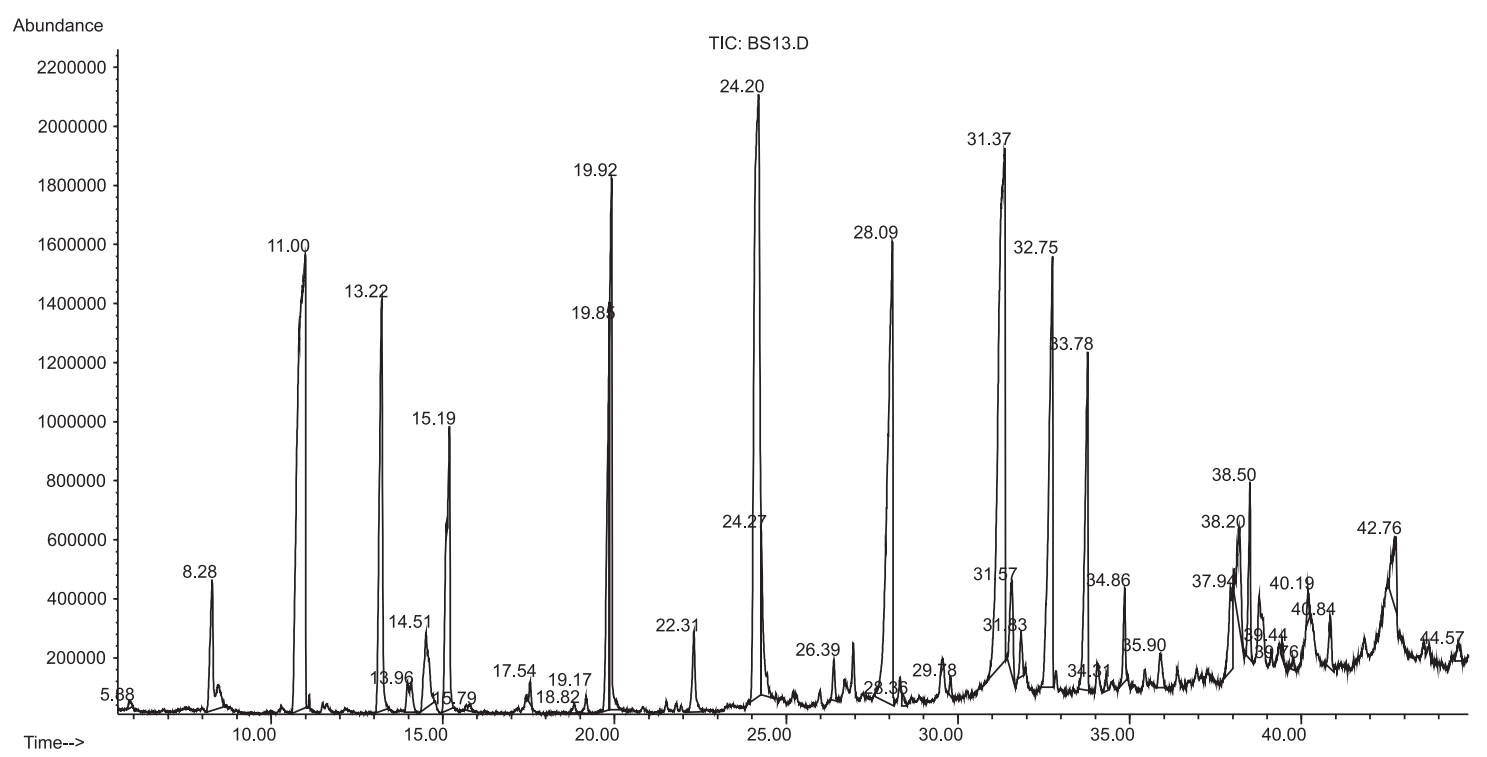

Fig. 2. The chromatogram of fatty acids from C. kansuensis Wils. flowers.

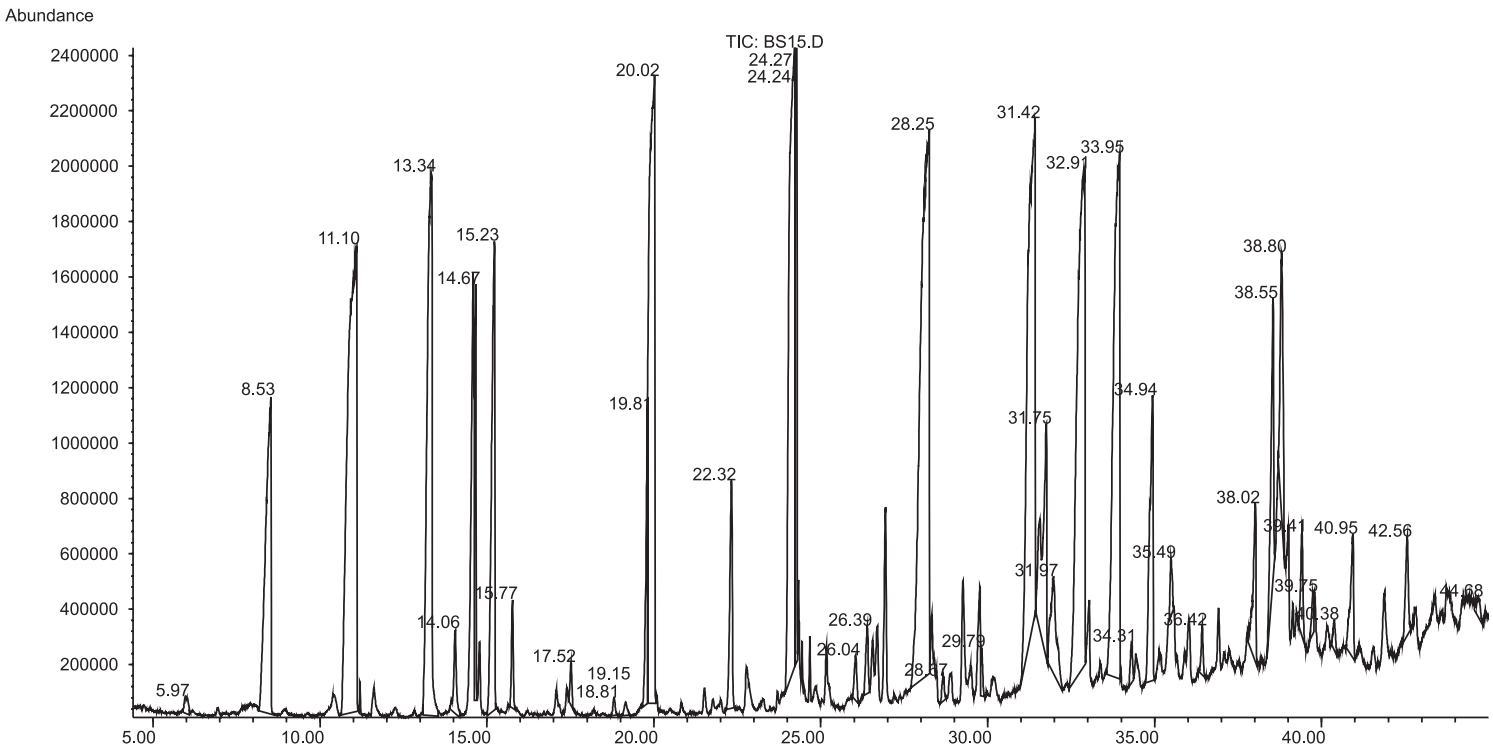

Time-->

Fig. 3. The chromatogram of fatty acids from C. Maximowizchii C.K. Schneid.

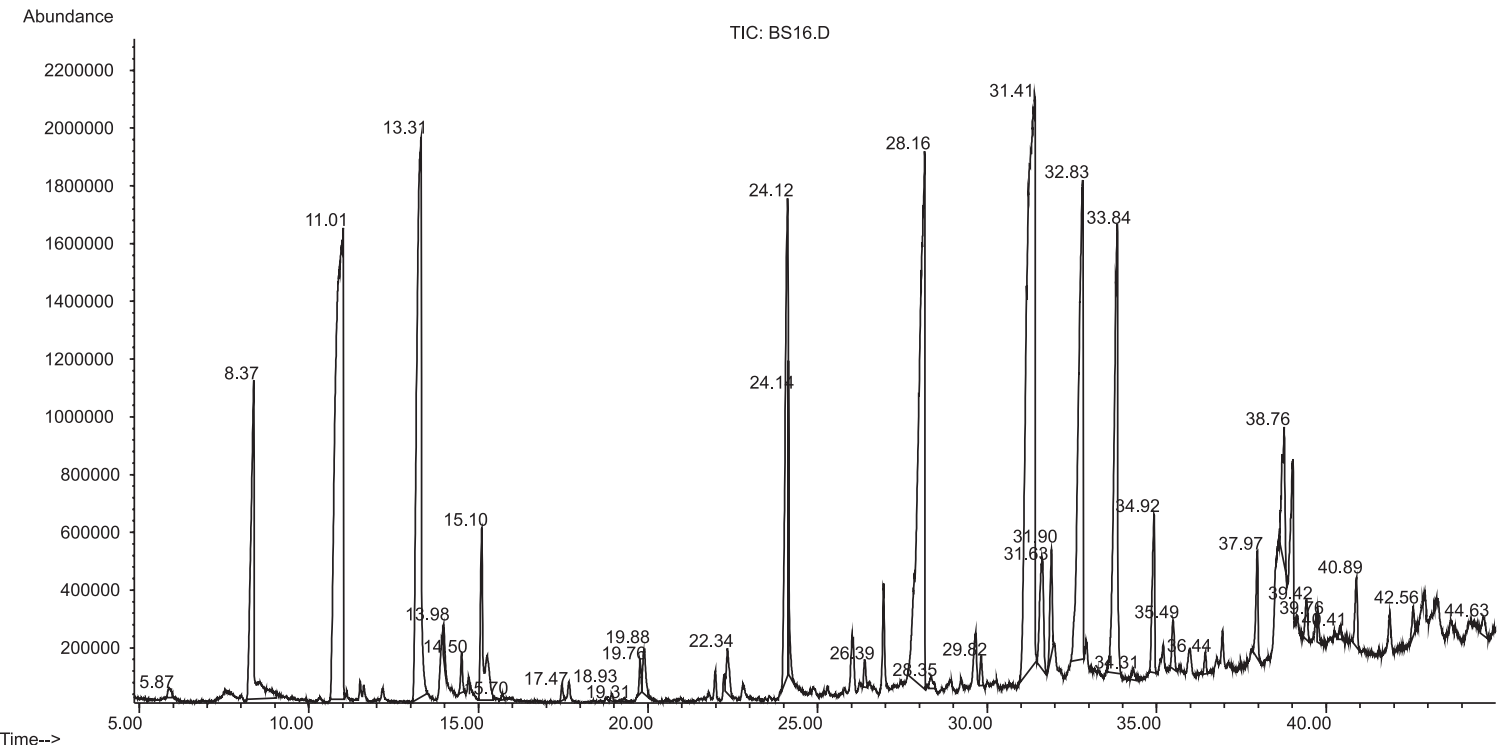

Fig. 4. The chromatogram of fatty acids from C. Schneideri C.K. Schneid. flowers. 
saturated $-64.73 \%$, unsaturated $-35.27 \%$; for C. kansuensis Wils. flowers: saturated $-65.59 \%$, unsaturated 34.41\%; for C. Maximowizchii C.K.Schneid. flowers: saturated $-57.71 \%$, unsaturated $-42.29 \%$; for C. Schneideri C.K.Schneid. flowers: saturated $-54.22 \%$, unsaturated $-45.78 \%$.

The highest content of oleic acid was determined in flowers of C. almaatensis Pojark. (4.5\%), linoleic acid - in flowers of C. kansuensis Wils. (20.37\%), linolenic acid - in flowers of C. Maximowizchii C.K.Schneid. (18.01\%).

\section{CONCLUSIONS}

1. The chromatography-mass spectrometry studies of fatty acids from flowers of $C$. almaatensis Pojark.,
C. kansuensis Wils., C. Maximowizchii C.K.Schneid. and C. Schneideri C.K. Schneid. of Sanguineae Sarg. section has been conducted.

2. In the raw material 17 fatty acids have been identified. For C. Maximowizchii C.K.Schneid. flowers pentadecanic acid is individual, and heneicosanic acid is individual for C. Schneideri C.K.Schneid. flowers.

3 . The saturated fatty acids dominate in all species studied; the unsaturated acids are presented by oleic, linoleic and linolenic acids. The highest content of oleic acid has been found in flowers of $C$. almaatensis Pojark. (4.5\%), linoleic acid- in flowers of $C$. kansuensis Wils. (20.37\%), linolenic acid - in flowers of C. Maximowizchii C.K.Schneid. (18.01\%).

\section{REFERENCES}

1. Гончаров Н.Ф., Сидора Н.В., Ковалева А.М., Комисаренко А.Н. // Рос. мед.-биол. вестник им. акад. Павлова. -2008 . - №3. - С. 150-154.

2. Деревья и кустарники СССР / Ред. С.И.Соколов. - М.: АН СССР. - 1954. - Т. 3. - С. 873.

3. Ковальова А.М., Сидора Н.В., Комісаренко А.М., Гончаров М.Ф. // Мед. хімія. - 2008. -№3. - С. 110-112.

4. Сидора Н.В., Ковальова А.М., Комісаренко А.М. // Актуальні питання фармаи. і мед. науки та практики. - 2012. - №2. - C. 26-30.

5. Флора УРСР / Ред. Д.К.Зеров. - К.: АН УРСР. - 1954. - T. 4. - С. 49-79.

6. Bicchi C., Brunelli C., Cordero C. // Ultrafast module-GC) for high-speed analysis of essential oils of differing complexities. - 2004. - Vol. 10, №1. - P. 195-207.

7. Carrapiso A.I., García C. // Lipids. - 2000. - №35 (11). - P. 1167-1177.

8. Phipps J.B. // Syst. Bot. - 1991. - Vol. 16, №4. - P. 303-332.

9. Quattrocchi U. CRC world dictionary of plant names: common names, scientific names, synonims and etymology. - Roca-Ratea, Florida, USA. - 2012. - Vol. 1. - 634 p.

10. Stuhlemmer U. // Phytotheur. - 2003. - №3. - P. 125-217.

\section{ПОРІВНЯЛЬНЕ ХІМІЧНЕ ДОСЛІДЖЕННЯ ЖИРНОКИСЛОТНОГО СКЛАДУ КВІТОК ГЛОДІВ CEKЦIÏ SANGUINEAE SARG.}

Н.В.Сидора, А.М.Ковальова, Ю.Н.Авідзба, А.М.Комісаренко

Ключові слова: глід; квітки; жирні кислоти

Хромато-мас-спектрометричним методом вперше проведено порівняльне дослідження жирнокислотного складу квіток C. almaatensis Pojark., C. kansuensis Wils., C. Schneideri C.K.Schneid. ma C. Maximowizchii C.K.Schneid. секції Sanguineae Sarg. Для дослідження використовували зразки сухої сировини, зібраної в фразу бутонізації на базі Ботанічного саду Національного університету ім. В.Н.Каразіна. Дослідження проводили на хроматографрі Agilent Technologies 6890 з мас-спектрометричним детектором 5973. В результаті в сировині було ідентифріковано 17 жирних кислот. В усіх досліджуваних видах за кількісним вмістом домінують насичені жирні кислоти: лауринова, міристинова, пентадеканова, пальмітинова, пальмітолеїнова, гептадеканова, стеаринова, арахінова, 2-оксипальмітинова, хенейкозанова, бегенова, гексадекандикарбонова, тетракозанова, гексакозанова. Ненасичені представлені олеїновою, лінолевою та ліноленовою кислотами. В квітках C. almaatensis Pojark. ідентифріковано 14 жирних кислот, C. kansuensis Wils. ma C. Schneideri C.K.Schneid. - 15, C. Maximowizchii C.K. Schneid - 17. Вміст жирних кислот (у перерахунку від загальної суми) для квіток C. almaatensis Pojark. склав: насичених - 64,73\%, ненасичених - 35,27\%; C. kansuensis Wils. насичених $-65,59 \%$, ненасичених - 34,41\%; C. Maximowizchii C.K. Schneid. насичених - 57,71\%, ненасичених 42,29\%; C. Schneideri C.K.Schneid. насичених - 54,22\%, ненасичених - 45,78\%. Найбільший вміст (у перерахунку від загальної суми жирних кислот) олеїнової кислоти визначено у квітках C. almaatensis Pojark. (4,5\%), лінолевої- у квітках C. kansuensis Wils. (20,37\%), ліноленової - у квітках C. Maximowizchii C.K.Schneid. (18,01\%). 


\section{СРАВНИТЕЛЬНОЕ ХИМИЧЕСКОЕ ИССЛЕДОВАНИЕ ЖИРНОКИСЛОТНОГО СОСТАВА ЦВЕТКОВ БОЯРЫШНИКОВ СЕКЦИИ SANGUINEAE SARG. Н.В.Сидора, А.М.Ковалева, Ю.Н.Авидзба, А.Н.Комиссаренко \\ Ключевые слова: боярышник; цветки; жирные кислоты}

Хромато-масс-спектрометрическим методом впервые проведено сравнительное изучение жирнокислотного состава цветков C. almaatensis Pojark., C. kansuensis Wils., C. Schneideri C.K.Schneid. и C. Maximowizchii C.K.Schneid. секции Sanguineae Sarg. Для исследования использовали образцы сухого сырья, собранного в фазу бутонизации на базе Ботанического сада Национального университета им. В.Н.Каразина. Исследование проводили на хроматоzpape Agilent Technologies 6890 с масс-спектрометрическим детектором 5973. В резульmame в сырье было идентифицировано 17 жирных кислот. Во всех исследованных видах по количественному содержанию доминируют насыщенные жирные кислоты: лауриновая, миристиновая, пентадекановая, пальмитиновая, пальмитолеиновая, гептадекановая, стеариновая, арахиновая, 2-оксипальмитиновая, хенейкозановая, бегеновая, гексадекандикарбоновая, тетракозановая, гексакозановая. Ненасыщенные представлены олеиновой, линолевой и линоленовой кислотами. В цветках C. almaatensis Pojark. идентифицировано 14 жирных кислот, C. kansuensis Wils. u C. Schneideri C.K.Schneid. - 15, C. Maximowizchii C.K.Schneid - 17. Содержание жирных кислот (в пересчете от общей суммы) для цветков C. almaatensis Pojark. составило: насыщенных - 64,73\%, ненасыщенных - 35,27\%; C. kansuensis Wils. насыщенных - 65,59\%, ненасыщенных - 34,41\%; C. Maximowizchii C.K.Schneid. насыщенных 57,71\%, ненасыщенных - 42,29\%; C. Schneideri C.K.Schneid. насыщенных - 54,22\%, ненасыщенных - 45,78\%. Наибольщее содержание (в пересчете от общей суммы жирных кислот) олеиновой кислоты установлено в цветках C. almaatensis Pojark. (4,5\%), линолевой - в цветках C. kansuensis Wils. (20,37\%), линоленовой - в цветках C. Maximowizchii C. K. Schneid. (18,01\%). 